\title{
Hydraulic Water Redistribution by Silver Fir (Abies alba Mill.) Occurring under Severe Soil Drought
}

\author{
Paul Töchterle ${ }^{1,2, t, * \mathbb{C}}$, Fengli Yang ${ }^{3,+}$, Stephanie Rehschuh ${ }^{1}$, Romy Rehschuh ${ }^{1}$, \\ Nadine K. Ruehr ${ }^{1}$, Heinz Rennenberg ${ }^{3}$ and Michael Dannenmann ${ }^{1}$ \\ 1 Institute of Meteorology and Climate Research, Atmospheric Environmental Research (IMK-IFU), \\ Karlsruhe Institute of Technology (KIT), Kreuzeckbahnstrasse 19, 82467 Garmisch-Partenkirchen, Germany; \\ stephanie.rehschuh@kit.edu (S.R.); romy.rehschuh@kit.edu (R.R.); nadine.ruehr@kit.edu (N.K.R.); \\ michael.dannenmann@kit.edu (M.D.) \\ 2 Institute of Geology, University of Innsbruck, Innrain 52f, 6020 Innsbruck, Austria \\ 3 Institut für Forstbotanik und Baumphysiologie, Freiburg University, Georges-Köhler Allee 53/54, \\ 79085 Freiburg, Germany; fengli.yang@ctp.uni-freiburg.de (F.Y.); \\ heinz.rennenberg@ctp.uni-freiburg.de (H.R.) \\ * Correspondence: paul.toechterle@kit.edu \\ + These authors contributed equally to this study.
}

Received: 20 December 2019; Accepted: 29 January 2020; Published: 31 January 2020

check for updates

\begin{abstract}
Hydraulic redistribution (HR) of water from wet- to dry-soil zones is suggested as an important process in the resilience of forest ecosystems to drought stress in semiarid and tropical climates. Scenarios of future climate change predict an increase of severe drought conditions in temperate climate regions. This implies the need for adaptations of locally managed forest systems, such as European beech (Fagus sylvatica L.) monocultures, for instance, through the admixing of deep-rooting silver fir (Abies alba Mill.). We designed a stable-isotope-based split-root experiment under controlled conditions to test whether silver fir seedlings could perform $\mathrm{HR}$ and therefore reduce drought stress in neighboring beech seedlings. Our results showed that HR by silver fir does occur, but with a delayed onset of three weeks after isotopic labelling with ${ }^{2} \mathrm{H}_{2} \mathrm{O}\left(\delta^{2} \mathrm{H} \approx+6000 \%\right.$ o), and at low rates. On average, $0.2 \%$ of added ${ }^{2} \mathrm{H}$ excess could be recovered via HR. Fir roots released water under dry-soil conditions that caused some European beech seedlings to permanently wilt. On the basis of these results, we concluded that HR by silver fir does occur, but the potential for mitigating drought stress in beech is limited. Admixing silver fir into beech stands as a climate change adaptation strategy needs to be assessed in field studies with sufficient monitoring time.
\end{abstract}

Keywords: hydraulic redistribution; drought; silver fir; European beech; mixed stand

\section{Introduction}

Hydraulic redistribution (HR) is the passive flux of water between wet- and dry-soil zones through plant roots as conduits. It is driven by soil-water potential gradients between dry- and wet-soil layers, and between roots and soil matrix [1,2]. Typically, HR occurs during the night, when transpiration has ceased [3-5]. Water can be redistributed in the upward (i.e., hydraulic lift [2,6,7]), downward (i.e., hydraulic descent [8-11]), and lateral directions [12-15]. Field observations showed that HR plays an important role in terrestrial ecohydrological cycles. Plants can benefit from HR through enhanced photosynthesis and transpiration [16], alleviated soil-moisture loss during the dry season [17], and a prolonged growing season $[18,19]$. These immediate benefits of HR consequently enhance nutrient acquisition [20], increase nutrient mobility, and facilitate root-litter decomposition [21,22]. 
HR has been documented in more than 100 species [23], including agricultural crops and grasses [24-26], and forest trees and shrubs [27-29]. Although HR has been observed in diverse climatic settings [16,23,30,31], it is most prevalent in arid and semiarid ecosystems, such as savannas [16,32,33], arid climates and semideserts [5,34-36], Mediterranean-type ecosystems [10,37-39], and tropical forests [40-42]. However, HR may become increasingly relevant in temperate ecosystems that are subject to intensified drying-wetting cycles due to extreme drought events in projected climate-change scenarios $[27,43]$.

Several techniques can be used to identify HR under laboratory or field conditions. Reverse water flow in roots can be identified by sap-flow techniques like the heat-balance $[29,44]$ or -ratio method $[45,46]$. However, quantification of reverse water flow in roots by sap-flow measurements can easily be disrupted by fluctuations in ambient temperature $[46,47]$, or small-scale soil and geomorphic variability [10]. Furthermore, sap flow can only be measured in individual roots and upscaling to the root system is a significant source of error [48]. Contrastingly, measurements of soil-water potential near plant roots, accompanied by water stable isotope analyses, have been used to track water movement in soil $[30,49,50]$. In this context, stable isotopes, either at natural abundance or by using heavy isotope enriched water (i.e., $\mathrm{H}_{2}{ }^{18} \mathrm{O},{ }^{2} \mathrm{H}_{2} \mathrm{O}$ ) as a tracer, are used as a novel technique to quantify water flow between dry- and wet-soil layers through plant roots and water uptake by adjacent plants [3,27,51].

In temperate forests, HR was only detected in a few tree species in the field, such as Norway spruce (Picea abies (L.) Karst.), Douglas fir (Pseudotsuga menziesii), ponderosa pine (Pinus Ponderosa), loblolly pine (Pinus taeda), and sessile oak (Quercus petraea) [51-55]. In an adult mixed oak/European beech forest, Zapater et al. [51] showed HR by oaks using an ${ }^{18} \mathrm{O}$-labelling approach but did not find any tracer material in European beech. However, both HR and the uptake of redistributed water by neighboring plants was detected in studies with seedlings of English oak, Norway spruce, and European beech under moderate drought in split-root systems in the greenhouse [27].

In Central Europe, European beech, being both an abundant natural tree species and a key species in forestry, was reported to be particularly vulnerable to drought $[56,57]$. As extreme drought events and intensified drying-wetting cycles are projected to become more prevalent $[43,58,59]$, beech forests in Central Europe face consequences such as declining growth and drastic economic losses for forestry [60-62]. Admixing deep-rooting tree species could potentially increase the resilience of beech stands. In this context, silver fir was proposed due to its high productivity and presumably higher drought resistance $[63,64]$. Furthermore, recent studies indicate that water supply to European beech in mixed forest stands may be supported by the presence of silver-fir neighbors $[65,66]$.

The aim of this study was to show if silver fir can perform HR under extreme drought conditions. For this purpose, we applied an improved split-root approach under controlled conditions, combined with the ${ }^{2} \mathrm{H}_{2} \mathrm{O}$ labelling of water and in situ stable isotope analysis of soil moisture. We hypothesized that fir roots were able to allocate ${ }^{2} \mathrm{H}_{2} \mathrm{O}$ from moist- to dry-soil zones by HR.

\section{Materials and Methods}

\subsection{Mesocosm Setup}

This study was conducted using plant-soil mesocosms under controlled conditions in the scientific greenhouse at the KIT Campus Alpin in Garmisch-Partenkirchen, Germany. Temperature (T) and relative humidity $(\mathrm{rH})$ were controlled and underwent daily cycles $\left(\mathrm{T}=20.5 \pm 4^{\circ} \mathrm{C}\right.$, and $\mathrm{rH}=58 \pm$ $12 \%$ on average). Ambient $\mathrm{CO}_{2}$ concentration showed diurnal fluctuations between 380 and 450 ppm without long-term trends during the timespan of the experiment.

Six mesocosms, each comprising 2 nested polyvinylchloride (PVC) compartments (dimensions of inner and outer compartment: length $\times$ width $\times$ height $=90 \times 38 \times 40 \mathrm{~cm}^{3}$ and $20 \times 20 \times 10 \mathrm{~cm}^{3}$, respectively) were set up as shown in Figures 1 and 2. Soil for the mesocosms was collected in autumn 2015 in the Black Forest close to Emmendingen (SW Germany). The material was taken from the Ah horizon of a Dystric Cambisol that originated from Triassic sandstone and showed a sandy loam texture 
(see [67] for site and soil details). The soil material was mixed with perlite at a volume ratio of 1:1. Perlite is a highly porous mineral that improves soil drainage and aeration properties while retaining moisture. These properties helped with the homogenization of soil moisture and isotope equilibration.
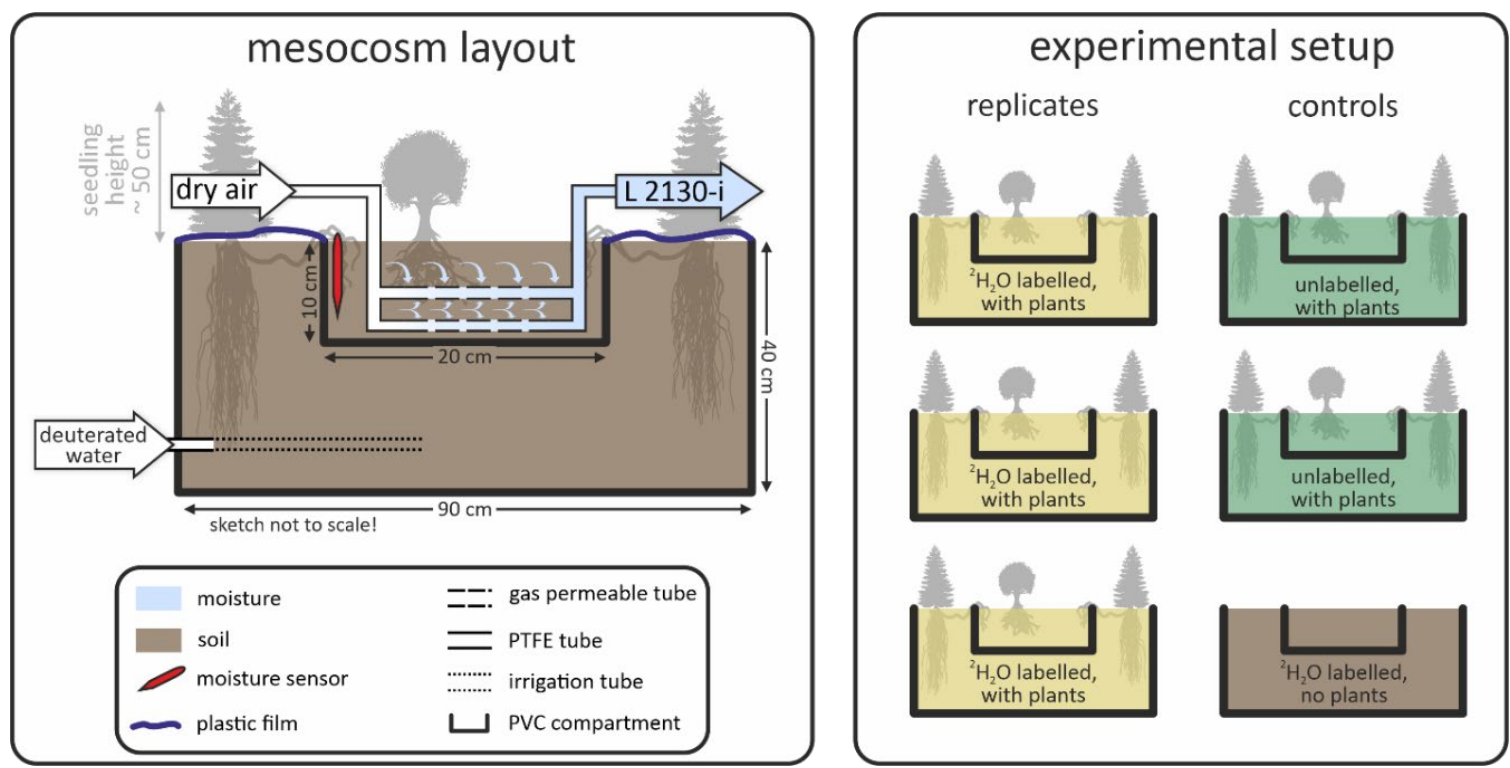

Figure 1. Experiment mesocosms. Two fir and 1 beech saplings were planted in polyvinylchloride (PVC) compartments, whereas a beech sapling was isolated within a smaller compartment in the center. A root strand of each fir was redirected into the beech compartment. Soil moisture was extracted via diffusion into dry air passing through gas-permeable tubing connected to a water isotope analyser (Picarro L 2130-i). Experiment comprised 6 such mesocosms; 3 were used as replicates and 3 as controls (see main text for more detail).

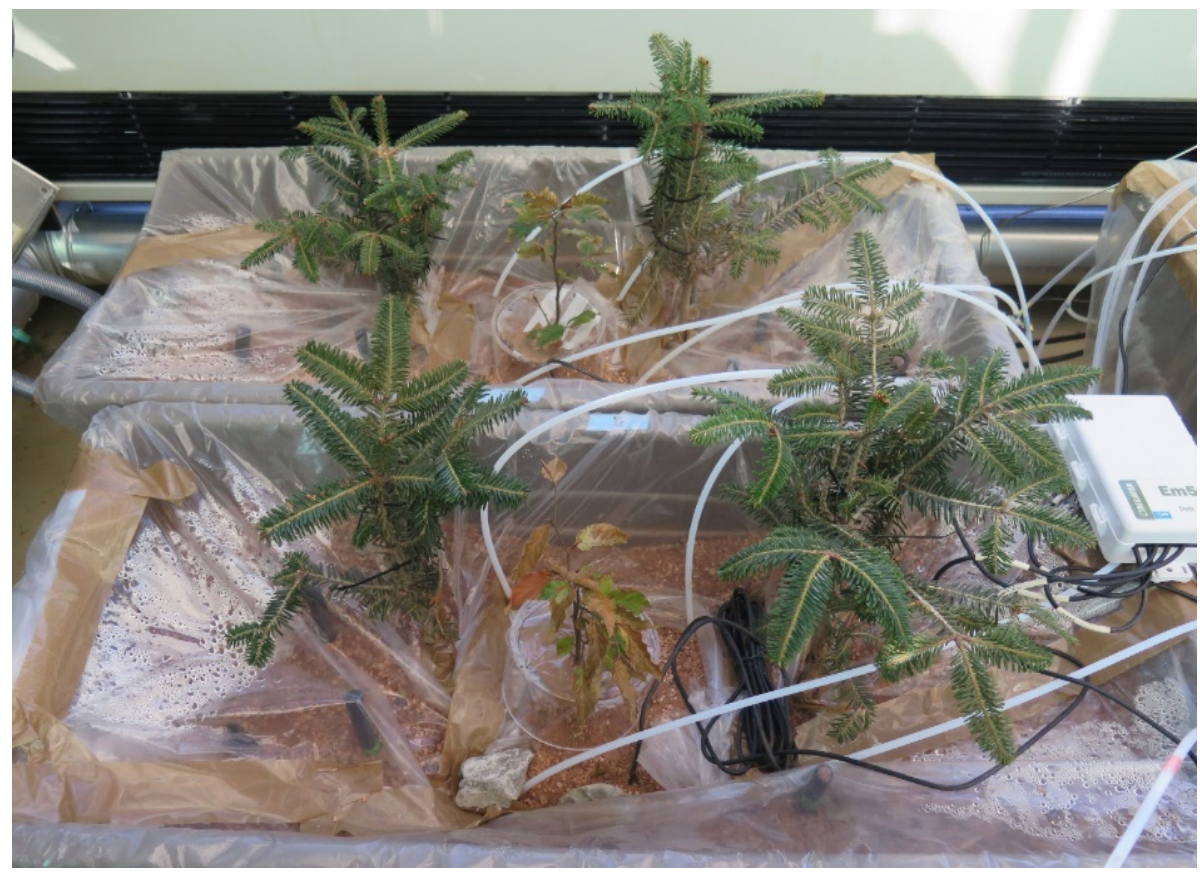

Figure 2. Photo of two mesocosms with silver-fir and European beech saplings in separate compartments.

Two silver-fir seedlings (3.5 years of age) were planted in the outer compartment (hereafter referred to as the fir compartment), and a single European beech seedling (2 years of age) in the inner 
compartment (hereafter referred to as the beech compartment). Root length of the fir and beech seedlings was, on average, 30 and $15 \mathrm{~cm}$, respectively. A first-order coarse root with intact second- and third order fine roots of each silver fir seedling was redirected to the beech compartment. The mesocosms were then wrapped with plastic film to avoid evaporation and consequent contamination of the lab environment with ${ }^{2} \mathrm{H}_{2} \mathrm{O}$ vapor. The fir-root strands were the only hydraulic connection between beech and fir compartments. As experiment control, 1 mesocosm was left unplanted but otherwise received identical treatment (Figure 1).

\subsection{Environmental Parameters}

Volumetric soil moisture and temperature were measured using DECAGON EM50 loggers (Decagon Devices, Inc., Pullman, Washington, DC, USA). A soil-moisture sensor (Type GS1 and 5TM, Decagon Devices, Inc., Pullman, WA, USA) was vertically installed in each beech compartment at approximately $10 \mathrm{~cm}$ depth. Volumetric water content (VWC) was recorded every 2 hours. Reported soil-moisture data were calibrated against gravimetric measurements of the same soil material used in the HR experiment. We observed erratic readings from soil-moisture sensors at very low soil-water contents. This had implications on the calculation of soil-water potential, as is explained in the following section.

\subsection{Soil-Water Potential}

Soil-water potential was calculated for the beech compartments with a widely used model for water retention in soils [68]:

$$
\theta=\theta_{r}+\frac{\left(\theta_{s}-\theta_{r}\right)}{\left(1+(\alpha|\Psi|)^{n}\right)^{m}}
$$

where $|\Psi|=\frac{1}{\alpha} \times\left\{\left(\frac{\left(\theta-\theta_{r}\right)}{\left(\theta_{s}-\theta_{r}\right)}\right)^{-\frac{1}{m}}-1\right\}^{\frac{1}{n}}$, and $\Psi$ is the absolute value of soil-water potential $(\mathrm{hPa} / \mathrm{cm}$ water column) at a specific volumetric water content $\theta\left(\mathrm{cm}^{3} \mathrm{~cm}^{-3}\right) . \theta_{\mathrm{s}}$ and $\theta_{r}$ were the saturated and residual water content of the soil, respectively. Parameters $\alpha(\mathrm{hPa}), \mathrm{n}$, and $\mathrm{m}$ are shape parameters. For fitting, $\theta_{\mathrm{s}}$ and $\theta_{r}$ were determined from measurements, and $\alpha$ and $\mathrm{n}$ were estimated using the soil texture of the potting substrate (sandy loam texture) according to Hodnett et al. [69]. For calculation, we used gravimetrically calibrated volumetric soil moisture. We conducted predawn water potential $\left(\Psi_{\text {predawn }}\right)$ measurements on 2 October to validate model results. $\Psi_{\text {predawn }}$ was measured on beech branches using a Scholander pressure chamber [70] (Model 1000 Pressure Chamber Instrument, PMS Instrument Company, Albany, Oregon, USA). Plant $\Psi_{\text {predawn }}$ could be used as an estimate for soil $\Psi$ on the basis of the assumption that plant $\Psi_{\text {predawn }}$ was in equilibrium with soil $\Psi$ adjacent to roots. Water potential is expressed as $\mathrm{pF}$ values, which is the logarithm of the absolute values of $\Psi(\mathrm{hPa})$. Due to potential biases inherent to VWC measurements at very dry soil conditions, $\mathrm{pF}$ calculation can be subject to large uncertainty leading to $\mathrm{pF}$ values above the physical limit of $\sim 6.9$.

\subsection{Leaf-Gas Exchange Measurements}

Leaf-gas exchange measurements on beech seedlings were performed from August to October, and captured the drought response of beech. We measured light-saturated photosynthesis $\left(A_{\text {sat }}\right)$ and stomatal conductance $\left(g_{s}\right)$ using a portable leaf-gas exchange system (Li-6400, LI-COR Inc., Lincoln, NE, USA) equipped with a light source (Li-6400-02B LED, LI-COR Inc., Lincoln, NE, USA). One green leaf per beech tree was measured under predetermined saturated light conditions (PAR $=1200 \mu \mathrm{mol}$ $\mathrm{m}^{-2} \mathrm{~s}^{-1}$ ), an average leaf temperature of $27.7^{\circ} \mathrm{C}$, and average relative humidity of $54 \%$. 


\subsection{Hydraulic-Redistribution Experiment}

Prior to the experiment, the VWC of beech compartments was maintained at roughly $15 \%$ by irrigation. Each mesocosm was then exposed to drought conditions by withholding irrigation for 25 days. On the night from 27 to 28 August, $2 \mathrm{~L}$ (i.e., $\left.5.8 \mathrm{~L} \mathrm{~m}^{-2}\right)$ of deuterated water $\left(\delta^{2} \mathrm{H} \approx+6000 \%\right.$ o) was injected into the bottom-soil zone of the fir compartment of 3 mesocosms containing trees and the unplanted control mesocosm. For each fir compartment, 6 evenly spread-out irrigation tubes (Figure 1) were used as injection ports in order to ensure the homogeneous distribution of deuterated water. The two remaining mesocosms containing trees received no label injection. Isotopic composition of soil moisture in the beech compartment was measured on 15 separate days during the 10 following weeks. Measurements generally took place during the morning hours until noon. Each beech compartment was re-watered on 29 October with $1.5 \mathrm{~L}$ of tap water in order to weaken the water-potential gradient between the fir and beech compartments, and, thus, the required conditions for HR.

\subsection{Deuterated-Water Tracing}

We used a membrane-inlet water-vapor sampling technique in soil coupled to a cavity ringdown laser spectrometer [71,72] to trace ${ }^{2} \mathrm{H}_{2} \mathrm{O}$ transport from the fir to the beech compartment. For this purpose, the beech compartment of each mesocosm was equipped with gas-permeable tubing (Accurel PP V8/2HF polypropylene tubing, Membrana $\mathrm{GmbH}$, Germany: $30 \mathrm{~cm}$ long sections buried at 5 and $10 \mathrm{~cm}$ depth) that was flushed with synthetic dry air $\left(20 \% \mathrm{O}_{2}\right.$ in $\left.\mathrm{N}_{2}\right)$ during measurements (Figure 2). The dry air absorbed moisture upon passing the gas-permeable section. This approach resembled in situ soil air probes [72], but with double the length of gas-permeable tubes in each beech compartment. Accurel tubes are suitable for isotopic measurements, as they do not cause isotopic fractionation across a wide range of soil-moisture contents, and render possible vapor measurements in equilibrium with soil water [71].

A Picarro L 2130-i cavity ringdown spectrometer was used to analyze the stable isotopic composition $\left(\delta^{2} \mathrm{H}\right)$ of the gas stream. On measurement days, gas streams exiting each of the 6 mesocosms were continuously measured for at least $15 \mathrm{~min}$. To minimize carryover artefacts, lines were flushed for $20 \mathrm{~min}$ between each measurement, and the values for the first $5 \mathrm{~min}$ of each measurement were ignored. Stable isotope data reported in the results section of this study refer to the average values of the remaining measurement time. Results of each day were scale-normalized to 2 in-house standards $\left(\delta^{2} \mathrm{H}=-235.0 \pm 1.8 \%\right.$ ond $1.8 \pm 0.9 \%$ VSMOW $)$ that were calibrated against international reference materials (VSMOW2, SLAP2).

HR was quantified in this study as a percentage of excess deuterium (d) added to the fir compartment by labelling, that was recovered in the beech compartment. In other words, ${ }^{2} \mathrm{H}$ excess recovery $(\Delta d)$ corresponds to the needed amount of ${ }^{2} \mathrm{H}$ from labelled water to reach the measured isotopic composition of a defined volume of water. We used isotopic measurements to calculate a mixing ratio between labelled water (i.e., $\delta^{2} \mathrm{H}=+6000 \%$ ) and background moisture using the isotopic composition of the control mesocosm as a baseline to account for natural variability. This mixing ratio is used to determine the amount of excess ${ }^{2} \mathrm{H}$ in beech compartments, relative to excess ${ }^{2} \mathrm{H}$ in the label water based on the VWC $(\theta)$ of the beech compartment and the amount of added label water (Equation 2):

$$
\Delta d=\frac{\Delta d_{\text {beech }}}{\Delta d_{\text {label }}} \times 100=\frac{\left(\varepsilon^{2} H_{\text {beech }}-\varepsilon^{2} H_{\text {control }}\right) \frac{m_{\text {bech }}}{m_{O}} \theta}{\left(\varepsilon^{2} H_{\text {label }}-\varepsilon^{2} H_{\text {control }}\right) \frac{m_{\text {label }}}{m_{O}} M_{\text {label }}} \times 100,
$$

where $\Delta d$ is the percentage of ${ }^{2} \mathrm{H}$ excess recovered in beech compartments, $\Delta d_{\text {beech }}$ and $\Delta d_{\text {label }}$ are the ${ }^{2} \mathrm{H}$ excess $[\mathrm{g}]$ in the respective water reservoir (i.e., beech compartment or deuterated label water), $\varepsilon^{2} H_{\text {beech }}, \varepsilon^{2} H_{\text {beech }}$, and $\varepsilon^{2} H_{\text {beech }}$ are the isotopic enrichment of the respective water reservoir (given in atomic $\%$ of deuterium calculated from $\delta^{2} \mathrm{H}$ values), $\frac{m_{\text {beech }}}{m_{O}}$ and $\frac{m_{\text {label }}}{m_{O}}$ are the molar weight ratio between hydrogen and oxygen in the respective water reservoir at the measured isotopic composition, $\theta$ is 
the VWC of beech compartments, and $M_{\text {label }}$ is the absolute amount of label water added to the fir compartment $[\mathrm{g}]$.

\section{Results and Discussion}

After 25 days of drought treatment, the VWC in the planted beech compartments declined to $6 \% \pm 2 \%$, while VWC in the unplanted control compartment was still at $16 \%$. Soil-water potential in the beech compartments of the mesocosms ranged between pF values of ca. 2.0 and 3.5 (Figure 3c). Net beech photosynthesis had declined to an average of $8 \mu \mathrm{mol} \mathrm{m} \mathrm{m}^{-2} \mathrm{~s}^{-1}$ (Figure 3a), and stomatal conductance showed values of around $0.14 \mathrm{~mol} \mathrm{~m}^{-2} \mathrm{~s}^{-1}$ (Figure $3 b$ ). After the fir compartments were labelled with $2 \mathrm{~L}$ of deuterated water, the net photosynthesis and stomatal conductance of beech continued to decline to $4 \mu \mathrm{mol} \mathrm{m} \mathrm{m}^{-2} \mathrm{~s}^{-1}$ and $0.05 \mathrm{~mol} \mathrm{~m}^{-2} \mathrm{~s}^{-1}$, respectively, one week after labelling.

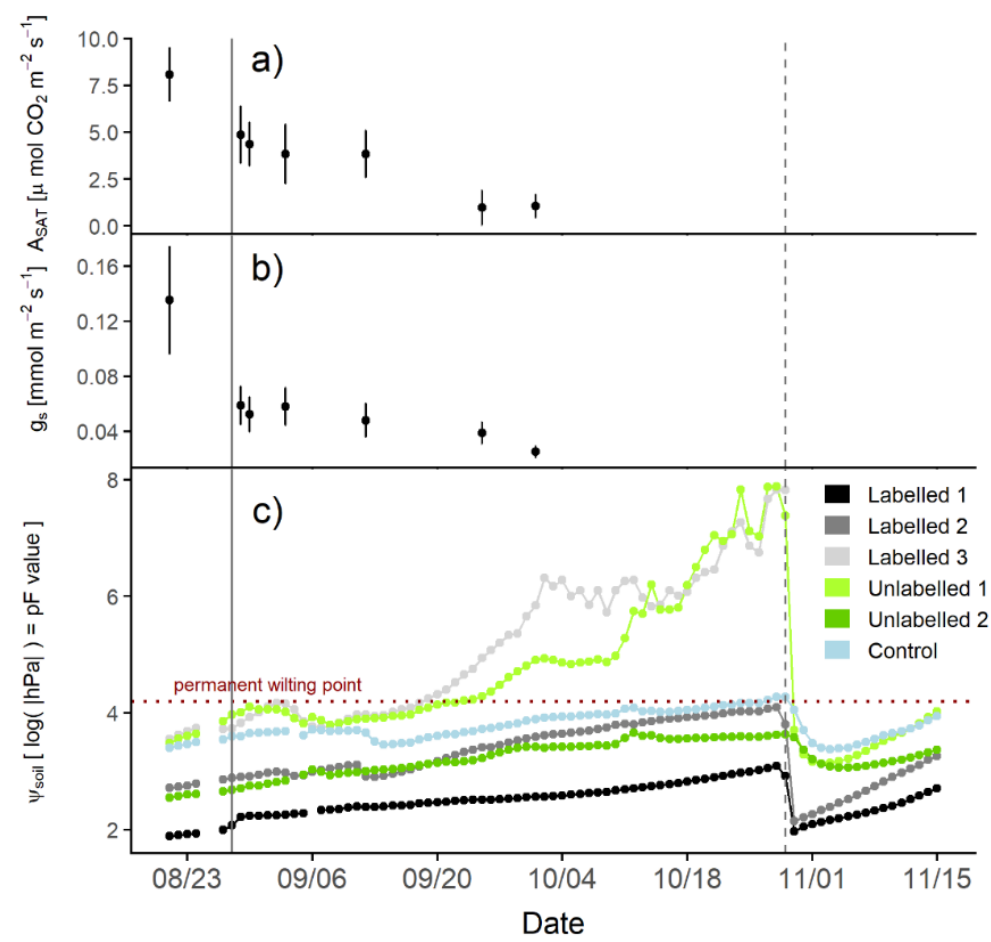

Figure 3. (a) Time series of light-saturated photosynthesis $\left(\mathrm{A}_{\mathrm{sat}}\right)$ and $(\mathbf{b})$ stomatal conductance $\left(\mathrm{g}_{\mathrm{s}}\right)$ of beech seedlings as measurement averages \pm standard error $(n=5)$. (c) Soil matrix potential in beech compartments (daily means) as $\mathrm{pF}$-values, $\log (|\mathrm{hPa}|)$ for three labelled (black, grey, light grey), two unlabelled (green, light green), and one unplanted control (light blue) mesocosms. Solid vertical line: time of deuterium labelling; dotted vertical line: re-watering of beech compartments. Very high $\mathrm{pF}$ values of some replicates from 10 April onwards were likely related to volumetric-water-content (VWC) measurement bias in very dry soil conditions.

These data showed that the beech trees experienced severe drought stress during the experiment that was not significantly counteracted by the silver-fir seedlings. Previous studies also reported a similar development for mature trees in the field under severe drought conditions at mixed fir and beech cultivation [66].

In unlabeled mesocosms and the labelled control mesocosm, $\delta^{2} \mathrm{H}$ values of soil moisture in the beech compartment remained between $-120 \%$ and $-80 \%$ VSMOW throughout the entire incubation period (Figure 4a). Labelled mesocosms showed similar or slightly enriched values for the first three weeks after labelling. In addition, ${ }^{2} \mathrm{H}$ excess recovery in the beech compartments was negligible during that time. This suggested that no detectable HR occurred for three weeks after label injection. 
a

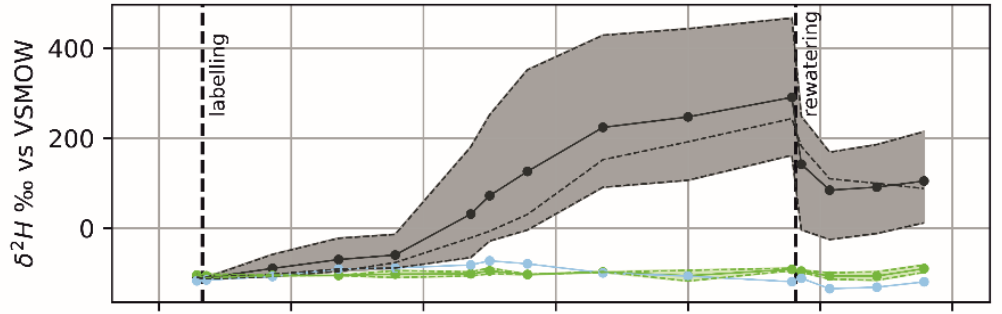

b

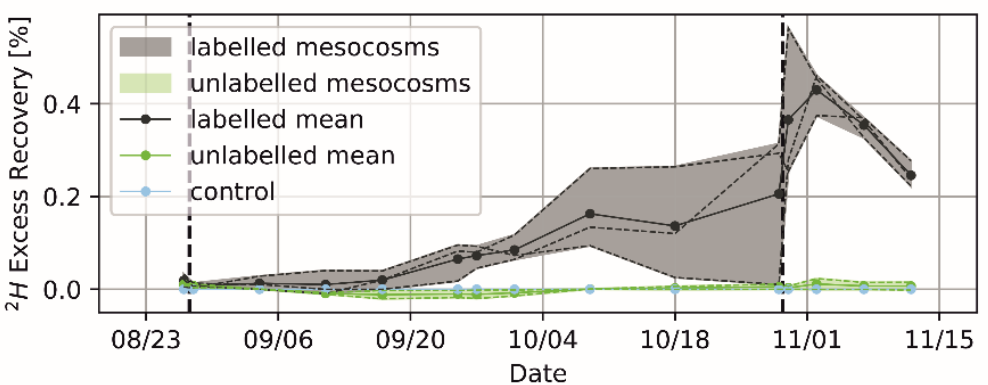

Figure 4. (a) Time series of $\delta^{2} \mathrm{H}$ in soil moisture in beech compartment of ${ }^{2} \mathrm{H}$-labeled mesocosms (grey), planted unlabelled mesocosms (green), and labelled control mesocosm without plants (light blue). Dashed lines: time series of each respective replicate; solid lines: their mean values. Re-watering was with unlabelled water. (b) Time series of ${ }^{2} \mathrm{H}$ excess recovery in beech compartments expressed as percentage of ${ }^{2} \mathrm{H}$ excess added by deuterated water to fir compartment. Isotopic composition of control mesocosms' beech compartment used as baseline for excess calculation. Grid was spaced at 14 day intervals.

During this initial three-week period, soil $\mathrm{pF}$ further increased in the beech compartments (Figure 3c). Values for $\delta^{2} \mathrm{H}$ in the beech compartments started to notably rise afterwards (Figure 4a). On the basis of ${ }^{2} \mathrm{H}$ excess recovery, we could assume that traceable amounts of water were reallocated to the beech compartment through the fir roots (Figure $4 b$ ). Hence, HR occurred in this experiment with a delay of ca. 2-3 weeks after label application. However, this delayed HR occurred at $\mathrm{pF}$ values above the permanent wilting point (i.e., $\mathrm{pF}=4.2$ according to Amelung et al. [73]; Figure 3c), and partially resulted in the wilting of the beech seedlings. Seedling wilting is also represented by the concurrent drop of photosynthetic activity and stomatal conductance to values close to zero (Figure 3a,b).

Prior to re-watering, ${ }^{2} \mathrm{H}$ excess recovered in the beech compartments amounted to an average of $0.2 \%$ of ${ }^{2} \mathrm{H}$ excess added with the $2 \mathrm{~L}$ of deuterated water (Figure $4 \mathrm{~b}$ ). Re-watering of the beech compartments with $1.5 \mathrm{~L}$ of water at the end of October clearly diluted the $\delta^{2} \mathrm{H}$ signal (Figure $4 \mathrm{a}$ ). Furthermore, $\mathrm{pF}$ values increased above the permanent wilting point. However, ${ }^{2} \mathrm{H}$ excess recovery was initially doubled by re-watering, followed by rapid decline (Figure $4 \mathrm{~b}$ ). We assumed that the unexpected doubling of ${ }^{2} \mathrm{H}$ excess upon re-watering was caused by overestimated VWC measurements directly after re-watering the beech compartments (water amount was part of the calculation of ${ }^{2} \mathrm{H}$ excess recovery; see Equation 2). As indicated by $\delta^{2} \mathrm{H}$ dynamics, re-watering seemed to eliminate the large gradient in water potential, which was needed to sustain HR through water loss from the fir roots.

Overall, $\delta^{2} \mathrm{H}$ was correlated to $\mathrm{pF}$ values in the beech compartments (Figure 5). This suggests that water-potential gradients largely drove HR by the silver-fir roots, and HR was stronger at high $\mathrm{pF}$ values. A similar observation was made in a loblolly pine stand, where hydraulic redistribution was determined by reverse root flow and was shown to increase with soil drought [74]. However, in split-root experiments for Norway spruce, European beech, and English oak, Hafner et al. [27] observed hydraulic redistribution already under moderate drought (water potential of ca. $-0.5 \mathrm{MPa} /$ $-5000 \mathrm{hPa} / \mathrm{pF}$ value of 3.7) after only several days. In these conditions, we could not find evidence to support HR at similar time scales. Still, our results were consistent with the observation that, in 
a mature mixed beech-fir forest, the presence of fir slightly improved the xylem-sap flow density of beech compared to a beech monoculture [66]. However, this improvement was not enough to counteract the negative effect of drought on xylem-sap flow density. In addition, the positive effect of the presence of fir on xylem-sap flow density in beech upon drought was reversed when the forest stand was subjected to precipitation after drought. These data indicated that cocultivation of beech and fir may not enhance the resilience of beech to drought events through HR.

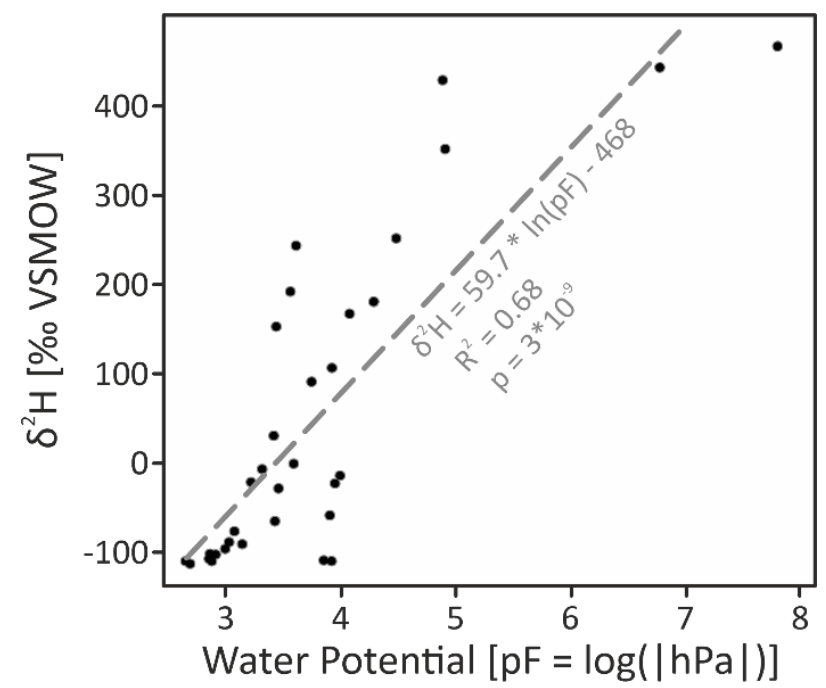

Figure 5. Relationship between $\delta^{2} \mathrm{H}$ and $\mathrm{pF}$ values in beech compartments of labelled mesocosms. Only incubation period from labelling until re-watering was considered.

\section{Conclusions}

We set up a split-root experiment with silver-fir and European beech seedlings using ${ }^{2} \mathrm{H}$ labelled water to track HR from wet- to dry-soil zones through silver-fir roots. In situ measurements of the isotopic composition of soil moisture showed detectable HR at 2-3 weeks after label application. A positive correlation between soil $\mathrm{pF}$ values and the isotopic composition of soil moisture confirmed that changes in water potential drive HR. Considering that only $0.2 \%$ of the added ${ }^{2} \mathrm{H}$ could be recovered at the permanent wilting point, we concluded that the admixing of silver fir to European beech stands likely does not increase the resilience of beech monocultures to severe drought conditions. The delayed onset of HR of 2-3 weeks in this study led us to recommend that future field studies allow for a longer monitoring time to fully detect hydraulic redistribution.

Author Contributions: Conceptualization, H.R., F.Y., P.T., and M.D.; methodology, P.T., F.Y., H.R., M.D., N.K.R.; data processing, P.T., F.Y., S.R., R.R.; writing—original-draft preparation, P.T., F.Y., M.D., H.R., S.R.; writing一review and editing, all authors; visualization, P.T., S.R.; supervision, H.R., M.D., N.K.R. All authors have read and agreed to the published version of the manuscript.

Funding: This study was funded by the Federal Ministry of Food and Agriculture (BMEL) within the "Waldklimafonds" program and the "Buchen-Tannen-Mischwälder zur Anpassung von Wirtschaftswäldern an Extremereignisse des Klimawandels (BuTaKli)" project; their support is gratefully acknowledged. Additional funding was provided by the German Federal Ministry of Education and Research (BMBF) through the Helmholtz Association and its ATMO research program. RR and NKR acknowledge support from the German Research Foundation through its Emmy Noether Program (RU 1657/2-1).

Acknowledgments: We would like to thank Andreas Gast, Nils Risse, and Stefanie Dumberger for their assistance with the experiment setup and leaf-gas exchange measurements. We would also like to acknowledge the two anonymous reviewers whose comments have greatly improved the manuscript.

Conflicts of Interest: The authors declare no conflict of interest. 


\section{References}

1. Lee, E.; Kumar, P.; Barron-Gafford, G.A.; Hendryx, S.M.; Sanchez-Cañete, E.P.; Minor, R.L.; Colella, T.; Scott, R.L. Impact of Hydraulic Redistribution on Multispecies Vegetation Water Use in a Semiarid Savanna Ecosystem: An Experimental and Modeling Synthesis. Water Resour. Res. 2018, 54, 4009-4027. [CrossRef]

2. Leffler, A.J.; Peek, M.S.; Ryel, R.J.; Ivans, C.Y.; Caldwell, M.M. Hydraulic Redistribution Through the Root Systems of Senesced Plants. Ecology. 2005, 86, 633-642. [CrossRef]

3. Caldwell, M.M.; Richards, J.H. Hydraulic lift: water efflux from upper roots improves effectiveness of water uptake by deep roots. Oecologia. 1989, 79, 1-5. [CrossRef] [PubMed]

4. Querejeta, J.I.; Egerton-Warburton, L.M.; Allen, M.F. Direct nocturnal water transfer from oaks to their mycorrhizal symbionts during severe soil drying. Oecologia. 2003, 134, 55-64. [CrossRef]

5. Snyder, K.A.; Richards, J.H.; Donovan, L.A. Night-time conductance in C3 and C4 species: do plants lose water at night? J. Exp. Bot. 2003, 54, 861-865. [CrossRef]

6. Sakuratani, T.; Aoe, T.; Higuchi, H. Reverse flow in roots of Sesbania rostrata measured using the constant power heat balance method. Plant Cell Environ. 1999, 22, 1153-1160. [CrossRef]

7. Sekiya, N.; Araki, H.; Yano, K. Applying hydraulic lift in an agroecosystem: forage plants with shoots removed supply water to neighboring vegetable crops. Plant Soil. 2011, 341, 39-50. [CrossRef]

8. Burgess, S.S.O.; Bleby, T.M. Redistribution of soil water by lateral roots mediated by stem tissues. J. Exp. Bot. 2006, 57, 3283-3291. [CrossRef]

9. Burgess, S.S.O.; Adams, M.A.; Turner, N.C.; Ong, C.K. The redistribution of soil water by tree root systems. Oecologia. 1998, 115, 306-311. [CrossRef]

10. Hultine, K.R.; Cable, W.L.; Burgess, S.S.O.; WILLIAMS, D.G. Hydraulic redistribution by deep roots of a Chihuahuan Desert phreatophyte. Tree Physiol. 2003, 23, 353-360. [CrossRef]

11. Nadezhdina, N.; David, T.S.; David, J.S.; Ferreira, M.I.; Dohnal, M.; Tesař, M.; Gartner, K.; Leitgeb, E.; Nadezhdin, V.; Cermak, J.; et al. Trees never rest: the multiple facets of hydraulic redistribution. Ecohydrol. 2010, 3, 431-444. [CrossRef]

12. Horton, J.L.; Hart, S.C. Hydraulic lift: a potentially important ecosystem process. Trends Ecol. Evolution. 1998, 13, 232-235. [CrossRef]

13. Neumann, R.B.; Cardon, Z.G. The magnitude of hydraulic redistribution by plant roots: a review and synthesis of empirical and modeling studies. New Phytol. 2012, 194, 337-352. [CrossRef]

14. Sardans, J.; Peñuelas, J. Hydraulic redistribution by plants and nutrient stoichiometry: Shifts under global change. Ecohydrol. 2014, 7, 1-20. [CrossRef]

15. Yu, K.; D'Odorico, P. From facilitative to competitive interactions between woody plants and plants with crassulacean acid metabolism (CAM): The role of hydraulic descent. Ecohydrol. 2017, 10, e1799. [CrossRef]

16. Scholz, F.G.; Bucci, S.J.; Hoffmann, W.A.; Meinzer, F.C.; Goldstein, G. Hydraulic lift in a Neotropical savanna: Experimental manipulation and model simulations. Agr. Forest Meteorol. 2010, 150, 629-639. [CrossRef]

17. Bleby, T.M.; McElrone, A.J.; Jackson, R.B. Water uptake and hydraulic redistribution across large woody root systems to $20 \mathrm{~m}$ depth. Plant Cell Environ. 2010, 33, 2132-2148. [CrossRef]

18. Bauerle, T.L.; Richards, J.H.; Smart, D.R.; Eissenstat, D.M. Importance of internal hydraulic redistribution for prolonging the lifespan of roots in dry soil. Plant Cell Environ. 2008, 31, 177-186. [CrossRef]

19. Scott, R.L.; Cable, W.L.; Hultine, K.R. The ecohydrologic significance of hydraulic redistribution in a semiarid savanna. Water Resour. Res. 2008, 44, 13. [CrossRef]

20. Cardon, Z.G.; Stark, J.M.; Herron, P.M.; Rasmussen, J.A. Sagebrush carrying out hydraulic lift enhances surface soil nitrogen cycling and nitrogen uptake into inflorescences. Proc. Natl. Acad. Sci. USA 2013, 110, 18988-18993. [CrossRef]

21. McCulley, R.L.; Jobbágy, E.G.; Pockman, W.T.; Jackson, R.B. Nutrient uptake as a contributing explanation for deep rooting in arid and semi-arid ecosystems. Oecologia. 2004, 141, 620-628. [CrossRef] [PubMed]

22. Quijano, J.C.; Kumar, P.; Drewry, D.T. Passive regulation of soil biogeochemical cycling by root water transport. Water Resour. Res. 2013, 49, 3729-3746. [CrossRef]

23. Wang, Y.; Jia, B.; Xie, Z. Impacts of hydraulic redistribution on eco-hydrological cycles: A case study over the Amazon basin. Sci. China Earth Sci. 2018, 61, 1330-1340. [CrossRef]

24. Corak, S.J.; Blevins, D.G.; Pallardy, S.G. Water Transfer in an Alfalfa/Maize Association: Survival of Maize during Drought. Plant Physiol. 1987, 84, 582-586. [CrossRef] 
25. Hirota, I.; Sakuratani, T.; Sato, T.; Higuchi, H.; Nawata, E. A split-root apparatus for examining the effects of hydraulic lift by trees on the water status of neighbouring crops. Agroforestry Systems. 2004, 60, 181-187. [CrossRef]

26. Smart, D.R.; Carlisle, E.; Goebel, M.; Nunez, B.A. Transverse hydraulic redistribution by a grapevine. Plant Cell Environ. 2005, 28, 157-166. [CrossRef]

27. Hafner, B.D.; Tomasella, M.; Häberle, K.-H.; Goebel, M.; Matyssek, R.; Grams, T.E.E. Hydraulic redistribution under moderate drought among English oak, European beech and Norway spruce determined by deuterium isotope labeling in a split-root experiment. Tree Physiol. 2017, 37, 950-960. [CrossRef]

28. Moreira, M.Z.; Scholz, F.G.; Bucci, S.J.; Sternberg, L.S.; Goldstein, G.; Meinzer, F.C.; Franco, A.C. Hydraulic lift in a neotropical savanna. Functional Ecology. 2003, 17, 573-581. [CrossRef]

29. Smith, D.M.; Jackson, N.A.; Roberts, J.M.; Ong, C.K. Reverse flow of sap in tree roots and downward siphoning of water by Grevillea robusta. Functional Ecology. 1999, 13, 256-264. [CrossRef]

30. Emerman, S.H.; Dawson, T.E. Hydraulic lift and its influence on the water content of the rhizosphere: an example from sugar maple, Acer saccharum. Oecologia. 1996, 108, 273-278. [CrossRef]

31. Prieto, I.; Armas, C.; Pugnaire, F.I. Hydraulic lift promotes selective root foraging in nutrient-rich soil patches. Functional Plant Biol. 2012, 39, 804. [CrossRef]

32. Ludwig, F.; Dawson, T.E.; Kroon, H.; Berendse, F.; Prins, H.H.T. Hydraulic lift in Acacia tortilis trees on an East African savanna. Oecologia. 2003, 134, 293-300. [CrossRef] [PubMed]

33. Yu, K.; D'Odorico, P. Hydraulic lift as a determinant of tree-grass coexistence on savannas. New Phytol. 2015, 207, 1038-1051. [CrossRef] [PubMed]

34. Ogle, K.; Lucas, R.W.; Bentley, L.P.; Cable, J.M.; Barron-Gafford, G.A.; Griffith, A.; Ignace, D.; Jenerette, G.D.; Tyler, A.; Huxman, T.E.; et al. Differential daytime and night-time stomatal behavior in plants from North American deserts. New Phytol. 2012, 194, 464-476. [CrossRef]

35. Yu, T.; Feng, Q.; Si, J.; Xi, H.; Li, Z.; Chen, A. Hydraulic redistribution of soil water by roots of two desert riparian phreatophytes in northwest China's extremely arid region. Plant Soil. 2013, 372, 297-308. [CrossRef]

36. Yu, T.; Feng, Q.; Si, J.; Zhang, X.; Alec, D.; Zhao, C. Evidences and magnitude of nighttime transpiration derived from Populus euphratica in the extreme arid region of China. J. Plant Biol. 2016, 59, 648-657. [CrossRef]

37. Hultine, K.R.; Scott, R.L.; Cable, W.L.; GOODRICH, D.C.; WILLIAMS, D.G. Hydraulic redistribution by a dominant, warm-desert phreatophyte: seasonal patterns and response to precipitation pulses. Functional Ecology. 2004, 18, 530-538. [CrossRef]

38. Hawkins, H.-J.; Hettasch, H.; West, A.G.; Cramer, M.D. Hydraulic redistribution by Protea 'Sylvia' (Proteaceae) facilitates soil water replenishment and water acquisition by an understorey grass and shrub. Functional Plant Biol. 2009, 36, 752. [CrossRef]

39. David, T.S.; Pinto, C.A.; Nadezhdina, N.; Kurz-Besson, C.; Henriques, M.O.; Quilhó, T.; Cermak, J.; Chaves, M.M.; Pereira, J.S.; David, J.S. Root functioning, tree water use and hydraulic redistribution in Quercus suber trees: A modeling approach based on root sap flow. Forest Ecology and Management. 2013, 307, 136-146. [CrossRef]

40. Meinzer, F.C.; Brooks, J.R.; Bucci, S.; Goldstein, G.; Scholz, F.G.; Warren, J.M. Converging patterns of uptake and hydraulic redistribution of soil water in contrasting woody vegetation types. Tree Physiol. 2004, 24, 919-928. [CrossRef]

41. Oliveira, R.S.; Dawson, T.E.; Burgess, S.S.O.; Nepstad, D.C. Hydraulic redistribution in three Amazonian trees. Oecologia. 2005, 145, 354-363. [CrossRef] [PubMed]

42. Scholz, F.G.; Bucci, S.J.; Meinzer, F.C.; Goldstein, G. Maintenance of Root Function in Tropical Woody Species During Droughts: Hydraulic Redistribution, Refilling of Embolized Vessels, and Facilitation Between Plants. In Tropical Tree Physiology-Adaptations and Responses in a Changing Environment; Santiago, L.S., Ed.; Springer International Publish: Cham, Switzerland, 2016; Volume 6, ISBN 978-3-319-27420-1.

43. IPCC. Climate Change 2014. The physical science basis: Working Group I contribution to the Fifth assessment report of the Intergovernmental Panel on Climate Change; Cambidge University Press: New York, NY, USA, 2014.

44. Green, S.R.; Clothier, B.E. Root water uptake by kiwifruit vines following partial wetting of the root zone. Plant Soil. 1995, 173, 317-328. [CrossRef]

45. Smith, D.M.; Allen, S.J. Measurement of sap flow in plant stems. J. Exp. Bot. 1996, 47, 1833-1844. [CrossRef] 
46. Lott, J.E.; Khan, A.A.H.; Ong, C.K.; Black, C.R. Sap flow measurements of lateral tree roots in agroforestry systems. Tree Physiol. 1996, 16, 995-1001. [CrossRef] [PubMed]

47. Khan, A.A.H.; Ong, C.K. Correction of Systematic Errors in Estimates of Transpiration Obtained Using a Constant Temperature Heat Balance Technique. Ex. Agric. 1995, 31, 461-472. [CrossRef]

48. Yu, T.; Feng, Q.; Si, J.; Mitchell, P.J.; Forster, M.A.; Zhang, X.; Zhao, C. Depressed hydraulic redistribution of roots more by stem refilling than by nocturnal transpiration for Populus euphratica Oliv. in situ measurement. Ecol. Evol. 2018, 8, 2607-2616. [CrossRef]

49. Dawson, T.E. Hydraulic lift and water use by plants: implications for water balance, performance and plant-plant interactions. Oecologia. 1993, 95, 565-574. [CrossRef]

50. Dawson, T.E.; Pate, J.S. Seasonal water uptake and movement in root systems of Australian phraeatophytic plants of dimorphic root morphology: a stable isotope investigation. Oecologia. 1996, 107, 13-20. [CrossRef]

51. Zapater, M.; Hossann, C.; Bréda, N.; Bréchet, C.; Bonal, D.; Granier, A. Evidence of hydraulic lift in a young beech and oak mixed forest using $18 \mathrm{O}$ soil water labelling. Trees. 2011, 25, 885-894. [CrossRef]

52. Nadezhdina, N.; Cermák, J.; Gaspárek, J.; Nadezhdin, V.; Prax, A. Vertical and horizontal water redistribution in Norway spruce (Picea abies) roots in the Moravian Upland. Tree Physiol. 2006, 26, 1277-1288. [CrossRef]

53. Nadezhdina, N.; Steppe, K.; de Pauw, D.J.W.; Bequet, R.; Cermak, J.; Ceulemans, R. Stem-mediated hydraulic redistribution in large roots on opposing sides of a Douglas-fir tree following localized irrigation. New Phytol. 2009, 184, 932-943. [CrossRef] [PubMed]

54. Brooks, J.R.; Meinzer, F.C.; Warren, J.M.; Domec, J.-C.; Coulombe, R. Hydraulic redistribution in a Douglas-fir forest: lessons from system manipulations. Plant Cell Environ. 2006, 29, 138-150. [CrossRef] [PubMed]

55. Brooks, J.R.; Meinzer, F.C.; Coulombe, R.; Gregg, J. Hydraulic redistribution of soil water during summer drought in two contrasting Pacific Northwest coniferous forests. Tree Physiol. 2002, 22, 1107-1117. [CrossRef] [PubMed]

56. Fotelli, M.N.; Nahm, M.; Radoglou, K.; Rennenberg, H.; Halyvopoulos, G.; Matzarakis, A. Seasonal and interannual ecophysiological responses of beech (Fagus sylvatica) at its south-eastern distribution limit in Europe. Forest Ecology and Management. 2009, 257, 1157-1164. [CrossRef]

57. Simon, J.; Dannenmann, M.; Pena, R.; Gessler, A.; Rennenberg, H. Nitrogen nutrition of beech forests in a changing climate: importance of plant-soil-microbe water, carbon, and nitrogen interactions. Plant Soil. 2017, 418, 89-114. [CrossRef]

58. Knoke, T.; Hahn, A. Global Change and the Role of Forests in Future Land-Use Systems. Climate Change, Air Pollution and Global Challenges - Understanding and Perspectives from Forest Research; Elsevier: Amsterdam, Netherlands, 2013; ISBN 9780080983493.

59. Zimmermann, J.; Hauck, M.; Dulamsuren, C.; Leuschner, C. Climate Warming-Related Growth Decline Affects Fagus sylvatica, But Not Other Broad-Leaved Tree Species in Central European Mixed Forests. Ecosystems. 2015, 18, 560-572. [CrossRef]

60. Rennenberg, H.; Seiler, W.; Matyssek, R.; Gessler, A.; Kreuzwieser, J. Die Buche (Fagus sylvatica L.) - ein Waldbaum ohne Zukunft im südlichen Mitteleuropa. Allg. Forst- u. J.-Ztg. 2004, 175, 210-224.

61. Piovesan, G.; Biondi, F.; di Filippo, A.; Alessandrini, A.; Maugeri, M. Drought-driven growth reduction in old beech (Fagus sylvatica L.) forests of the central Apennines, Italy. Global Change Biol. 2008, 14, 1265-1281. [CrossRef]

62. Hanewinkel, M.; Cullmann, D.A.; Schelhaas, M.-J.; Nabuurs, G.-J.; Zimmermann, N.E. Climate change may cause severe loss in the economic value of European forest land. Nature Clim Change. 2013, 3, $203-207$. [CrossRef]

63. Bouriaud, O.; Popa, I. Comparative dendroclimatic study of Scots pine, Norway spruce, and silver fir in the Vrancea Range, Eastern Carpathian Mountains. Trees. 2009, 23, 95-106. [CrossRef]

64. Feliksik, E.; Wilczyński, S. The Effect of Climate on Tree-Ring Chronologies of Native and Nonnative Tree Species Growing Under Homogenous Site Conditions. Geochronometria. 2009, 33, 49-57. [CrossRef]

65. Magh, R.-K.; Grün, M.; Knothe, V.E.; Stubenazy, T.; Tejedor, J.; Dannenmann, M.; Rennenberg, H. Silver-fir (Abies alba MILL.) neighbors improve water relations of European beech (Fagus sylvatica L.), but do not affect N nutrition. Trees. 2018, 32, 337-348. [CrossRef]

66. Magh, R.K.; Bonn, B.; Grote, R.; Burzlaff, T.; Pfautsch, S.; Rennenberg, H. Drought Superimposes the Positive Effect of Silver Fir on Water Relations of European Beech in Mature Forest Stands. Forests. 2019, 10, 897. [CrossRef] 
67. Rehschuh, S.; Fuchs, M.; Tejedor, J.; Schäfler-Schmid, A.; Magh, R.-K.; Burzlaff, T.; Rennenberg, H.; Dannenmann, M. Admixing Fir to European Beech Forests Improves the Soil Greenhouse Gas Balance. Forests. 2019, 10, 213. [CrossRef]

68. van Genuchten, M.T. A Closed-form Equation for Predicting the Hydraulic Conductivity of Unsaturated Soils1. Soil Science Society of America Journal. 1980, 44, 892. [CrossRef]

69. Hodnett, M.G.; Tomasella, J. Marked differences between van Genuchten soil water-retention parameters for temperate and tropical soils: a new water-retention pedo-transfer functions developed for tropical soils. Geoderma. 2002, 108, 155-180. [CrossRef]

70. Scholander, P.F.; Hammel, H.T.; Hemmingsen, E.A.; Bradstreet, E.D. Hydrostatic Pressure and Osmotic Potential in Leaves of Mangroves and some other Plants. Proc. Natl. Acad. Sci. U. S. A. 1964, 52, 119-125. [CrossRef]

71. Rothfuss, Y.; Vereecken, H.; Brüggemann, N. Monitoring water stable isotopic composition in soils using gas-permeable tubing and infrared laser absorption spectroscopy. Water Resour. Res. 2013, 49, 3747-3755. [CrossRef]

72. Oerter, E.J.; Bowen, G. In situ monitoring of $\mathrm{H}$ and $\mathrm{O}$ stable isotopes in soil water reveals ecohydrologic dynamics in managed soil systems. Ecohydrol. 2017, 10, e1841. [CrossRef]

73. Amelung, W.; Blume, H.-P.; Fleige, H.; Horn, R.; Kandeler, E.; Kögel-Knabner, I.; Kretzschmar, R.; Stahr, K.; Wilke, B.-M. Scheffer/Schachtschabel Lehrbuch der Bodenkunde; Springer Berlin Heidelberg: Berlin, Heidelberg, Germany, 2018; p. 243. ISBN 978-3-662-55870-6.

74. Domec, J.-C.; King, J.S.; Noormets, A.; Treasure, E.; Gavazzi, M.J.; Sun, G.; McNulty, S.G. Hydraulic redistribution of soil water by roots affects whole-stand evapotranspiration and net ecosystem carbon exchange. New Phytol. 2010, 187, 171-183. [CrossRef]

(C) 2020 by the authors. Licensee MDPI, Basel, Switzerland. This article is an open access article distributed under the terms and conditions of the Creative Commons Attribution (CC BY) license (http://creativecommons.org/licenses/by/4.0/). 